\title{
Correlations between InCRNA-SOX2OT polymorphism and susceptibility to breast cancer in a Chinese population
}

\begin{abstract}
Aim: We evaluated the effect of IncRNA SOX2OT expression and its SNP in tumorigenesis and development of breast cancer (BC) in a case-control study. Methods: A total of 1106 individuals, 505 newly diagnosed BC patients and 601 age-matched controls ( \pm 2 years) were testified. Real-time PCR was adopted for testing tissues' SOX2OT expression. Genotyping of rs9839776 were conducted by using SNaPshot assays. Results: SOX2OT were overexpressed in BC tissues $(p<0.001)$. SOX2OT SNP rs9839776 was strongly associated with the higher expression of SOX2OT and an increased risk of $\mathrm{BC}$ in Chinese women (odds ratio: $1.42 ; 95 \% \mathrm{Cl}: 1.06-1.90 ; \mathrm{p}=0.018$ ). Conclusion: These results confirmed that BC was conspicuously associated with higher SOX2OT expression. SOX2OT SNP rs9839776 was significantly associated with the onset of BC possibly via influencing the expression of SOX2OT.
\end{abstract}

First draft submitted: 23 August 2016; Accepted for publication: 15 December 2016; Published online: 17 February 2017

Keywords: breast cancer $\bullet$ long noncoding RNA • polymorphism • SOX2OT

Breast cancer (BC), also known as breast tumor, is one of the most frequently diagnosed malignant tumors and the major life-threatening diseases for women worldwide. According to the statistics of International Agency for Research on Cancer, there were 1.38 million new cases of BC, which accounted for $22.9 \%$ of all female malignant tumor incidences. A total of 460 thousand deaths were caused by BC, accounting for $13.7 \%$ of all female malignant tumor mortality worldwide in 2008 [1]. BC is the second most common malignant tumor for Chinese women. In China, there were approximately 169 thousand new female patients with $\mathrm{BC}$ and 45 thousand died of $\mathrm{BC}$ each year [2]. For the $\mathrm{BC}$ survival rate, according to the statistics from 1995 to 2007 in developed countries such as Australia, Canada, Denmark and the UK, the 5-year survival rate of $\mathrm{BC}$ patients could be up to $85-90 \%$ [3]. In the urban areas of China, the 5-year survival rate of BC patients was $70 \%$ and was increasing gradually. Although traditional treatments such as radiotherapy, chemotherapy and surgery have evolved and improved substantially, the cure rate of $\mathrm{BC}$ is still poor [4]. Recent studies have provided evidence that the pathogenesis of $\mathrm{BC}$ is complicated and environmental and genetic factors (as well as their potential interactions) contribute to the occurrence and development of $\mathrm{BC}$ [5]. Therefore, it is urgently required to promote effective markers of $\mathrm{BC}$ for early prognosis and intervention.

Long noncoding RNAs (lncRNAs, from 200 bases to $100 \mathrm{~kb}$ in length) are transcribed RNA molecules. Lacking an open reading frame, IncRNAs have no protein-coding capability [6]. IncRNAs are demonstrated to involve in numerous cellular and carcinogenesis processes, including cell growth [7], tumorigenesis [8] and transcriptional regulation [9]. lncRNAs are also associated with a number of diseases such as cardiovascular disease [10], neurodegeneration disease [11] and carcinoma [12]. So far, 17 lncRNAs have been identified for their crucial role in the tumor bio-
Xiuwu Tang ${ }^{\ddagger 1,}$, Yan Gao $\mathrm{Ga}^{\ddagger 2,3}$, Linxiang $\mathrm{Yu}^{\ddagger, 4}$, Yan $\mathrm{Lu}^{2,3}$ Guanglin Zhou ${ }^{5}$, Lifang Cheng ${ }^{6}$, Kai Sun 7 , Baoli Zhu ${ }^{3}$, Ming $X u^{*, 3,6}$ \& Jingjing Liu $u^{* *, 5}$

'Department of Gynecology \& Obstetrics, the First Affiliated Hospital of Soochow University, Suzhou, China

${ }^{2}$ Institute of Suzhou Biobank, Suzhou Center for Disease Prevention \& Control, Suzhou, Jiangsu, China

${ }^{3}$ Department of Occupational Disease Prevention, Jiangsu Provincial Center for Disease Control \& Prevention, Nanjing, China

${ }^{4}$ Cardiothoracic Surgery, Affiliated Hospital of Nanjing University of Traditional Chinese Medicine, Nanjing, China

${ }^{5}$ Third Department of Breast Cancer, China Tianjin Breast Cancer Prevention, Treatment \& Research center, Tianjin Medical University Institute \& Hospital, National Clinical Research Center of Cancer, Tianjin, China ${ }^{6}$ Department of Pharmaceutics, College of Pharmaceutical Science, Soochow University, Suzhou, Jiangsu, China ${ }^{7}$ Department of Emergency, the First Affiliated Hospital of Nanjing Medical University, Nanjing, China

*Author for correspondence: Tel.:/Fax: +862585393212 sosolou@126.com

**Author for correspondence: Tel.:/Fax: +8622 23340123 liu-9007@163.com ${ }^{\ddagger}$ Authors contributed equally 
logy of BC, including BCAR4, PVT1, MALAT1 and GAS5 according to the lncRNA disease database [13].

The effects of SNPs on functional lncRNAs are drawing more attention because of their potential influence on the risks of cancers, including BC: e.g., rs12325489 in the BC-related IncRNA-ENST00000515084 [14]. These evidences support the hypothesis that the SNPs in IncRNAs impact the occurrence and development of $\mathrm{BC}$ and other human cancers.

SOX2 overlapping transcript (SOX2OT) is an lncRNA located in the intronic region of $\mathrm{SOX} 2$ gene. Although recent studies have already demonstrated that the alterations of SOX2OT expression and successive change in SOX2 expression are associated with BC [15], the function of SOX2OT is not fully understood. The rs9839776 is an intron variant in the SOX2OT gene, and the only SNP reported in SOX2OT that has statistical significance for the expression of SOX2OT in one genome wide association study [16]. So far no study combining the effect of SOX2OT polymorphisms and $\mathrm{BC}$ risk has been performed in a Chinese population. In order to better understand its potential association with SOX2OT expression, we performed a case-control study to evaluate and quantify the association between rs $9839776 \mathrm{C}>\mathrm{T}$ and the BC risk in a Chinese population.

\section{Materials \& methods}

\section{Study subjects}

In the current study, a total of 1106 female participants, 505 patients with newly diagnosed BC and 601 age-

\begin{tabular}{|c|c|c|c|c|c|}
\hline \multirow[t]{2}{*}{ Variables } & \multicolumn{2}{|c|}{ Cases $(n=505)$} & \multicolumn{2}{|c|}{ Controls $(n=601)$} & \multirow[t]{2}{*}{ p-value } \\
\hline & $\mathrm{n}$ & $\%$ & $\mathbf{n}$ & $\%$ & \\
\hline \multicolumn{6}{|l|}{ Age (years): } \\
\hline- Mean \pm SD & $56.9 \pm 8.9$ & & $57.0 \pm 8.4$ & & \multirow{3}{*}{0.852} \\
\hline$-<55$ & 219 & 43.3 & 256 & 42.6 & \\
\hline$-\geq 55$ & 286 & 56.7 & 345 & 57.4 & \\
\hline \multicolumn{6}{|l|}{ Histological types: } \\
\hline - Invasive ductal carcinoma & 309 & 61.1 & - & - & - \\
\hline - Invasive lobular carcinoma & 196 & 38.9 & - & - & - \\
\hline \multicolumn{6}{|l|}{ Differentiation grade: } \\
\hline - Well (G1) & 55 & 11.0 & - & - & - \\
\hline - Moderate (G2) & 352 & 69.7 & - & - & - \\
\hline - Poor (G3) & 98 & 19.3 & - & - & - \\
\hline \multicolumn{6}{|l|}{ Tumor stage: } \\
\hline - pT1 $(<2 \mathrm{~cm})$ & 238 & 47.1 & - & - & - \\
\hline- pT2 $(2-5 \mathrm{~cm})$ & 207 & 41.0 & - & - & - \\
\hline - pT3 $(\geq 5 \mathrm{~cm})$ & 35 & 6.9 & - & - & - \\
\hline - pT4 (exophytic) & 25 & 5.0 & - & - & - \\
\hline \multicolumn{6}{|l|}{ Nodal status: } \\
\hline- pNO & 312 & 61.8 & - & - & - \\
\hline$-\mathrm{pN} 1$ & 144 & 28.5 & - & - & - \\
\hline$-\mathrm{pN2}$ & 49 & 9.7 & - & - & - \\
\hline \multicolumn{6}{|l|}{ Estrogen receptor: } \\
\hline - Positive & 306 & 60.6 & - & - & - \\
\hline - Negative & 199 & 39.4 & - & - & - \\
\hline \multicolumn{6}{|l|}{ Progesterone receptor: } \\
\hline - Positive & 276 & 54.7 & - & - & - \\
\hline - Negative & 229 & 45.3 & - & - & - \\
\hline
\end{tabular}




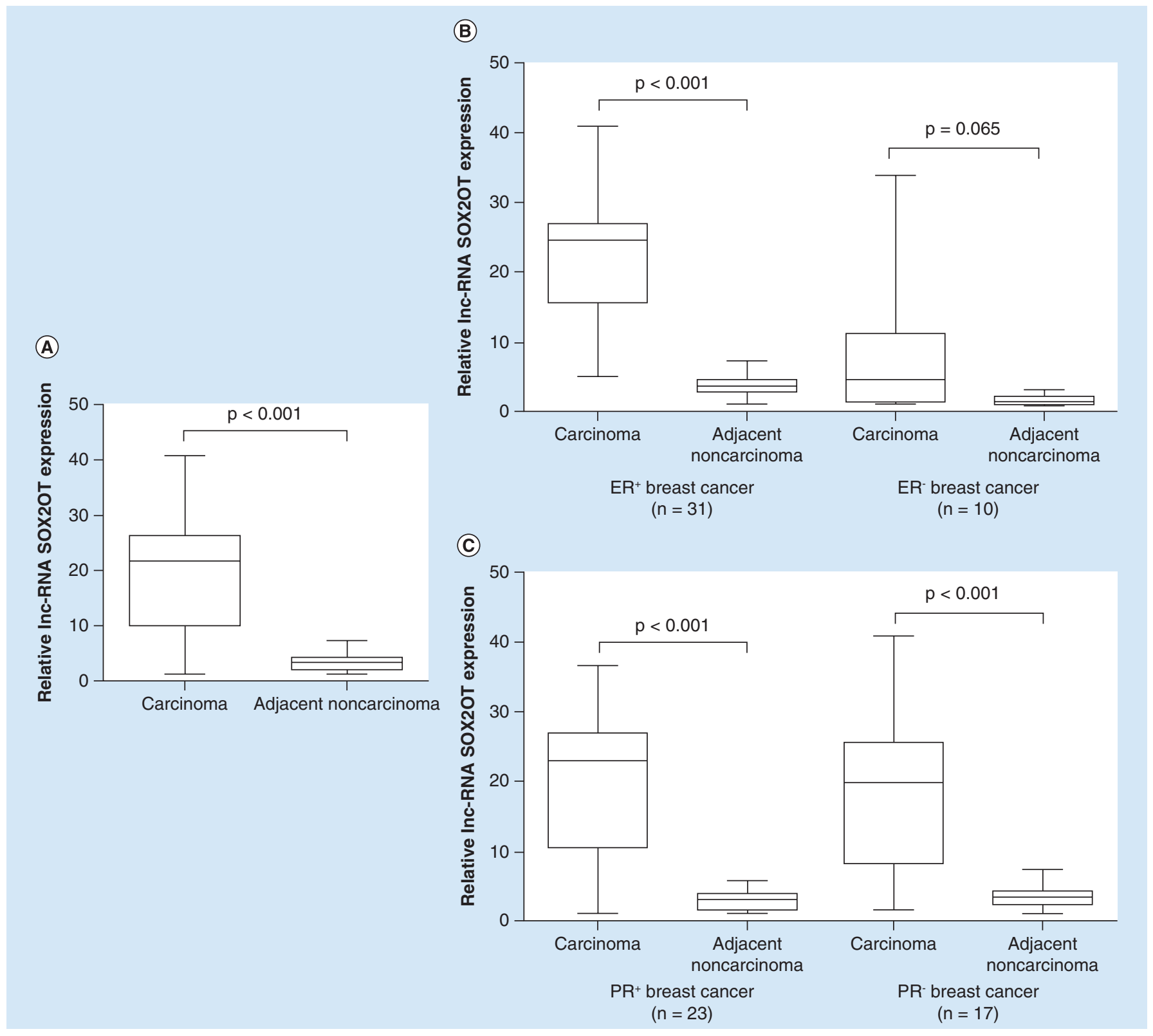

Figure 1. Expression of long noncoding RNA SOX2 overlapping transcript in both breast cancer tissues and adjacent normal tissues.

(A) The expression of SOX2 overlapping transcript relative to $\beta$-actin in 41 patients measured by quantitative real-time PCR. (B) The expression of SOX2 overlapping transcript in estrogen receptor $\left(^{+}\right)$and estrogen receptor $\left(^{-}\right)$patients. (C) The expression of SOX2OT in progesterone receptor $\left(^{+}\right)$and progesterone receptor $\left(^{-}\right)$patients.

ER: Estrogen receptor; IncRNA: long noncoding RNA; PR: Progesterone receptor; SOX2OT: SOX2 overlapping transcript.

matched ( \pm 2 years) controls, were recruited. All of the blood samples of subjects were collected by Suzhou Center for Disease Prevention and Control and Tianjin Medical University Institute and Hospital between June 2012 and April 2015. None of the patients had received radiotherapy, chemotherapy or endocrine therapy before blood collection. The control participants were free of any type of cancer history and were selected from 10,000 individuals who participated in a community-based chronic disease program of Suzhou
Center for Disease Prevention and Control during the same period as the cases were collected. At recruitment, informed consent was obtained from each participant. The study is in compliance with the Declaration of Helsinki and approved by the Research Ethics Committee of Jiangsu Provincial Center for Disease Prevention and Control (no. 2012025).

Cancerous tissues and noncancerous tissues were collected from 41 patients, involved in the total 503 patients, for further investigation of the SOX2OT 
expression in $\mathrm{BC}$ tissues and the association of SOX2OT SNP with the SOX2OT expression (data were shown in Supplementary Table 1).

\section{DNA \& RNA extraction}

A total of $5 \mathrm{ml}$ peripheral blood was collected in EDTA and taken for DNA isolation and genotyping. Genomic DNA was extracted from the blood samples of subjects by using the QIAcube HT Plasticware and QIAamp 96 DNA QIAcube HT Kit ${ }^{\circledR}$ (Qiagen, Dusseldorf, Germany) following the manufacturer's protocol and then stored at $-80^{\circ}$ until use.

\section{Genotype analysis}

In the current study, we conducted genotyping of SNP rs 9839776 by using SNaPshot assays. We first purified $2 \mu \mathrm{l} \mathrm{PCR}$ product with $0.3 \mu \mathrm{l}$ of shrimp alkaline phosphatase $^{\circledR}$ (Thermo Fisher Scientific, MA, USA) and incubated at $37^{\circ} \mathrm{C}$ for $100 \mathrm{~min}$ in turn $75^{\circ} \mathrm{C}$ for 15 min which will inactivate the enzyme. Then the purification of $\mathrm{SNaPshot} \mathrm{extension} \mathrm{reactions} \mathrm{was} \mathrm{con-}$ ducted in a volume of $5 \mu \mathrm{l}$ mixture which contains $2 \mu \mathrm{l}$ $\mathrm{SNaPshot}$ ready reaction $\mathrm{mix}^{\circledR}$ (Applied Biosystems, CA, USA), $1.5 \mu \mathrm{l}$ PCR product, and $1 \mu \mathrm{l}$ of extension primers. The PCR cycling conditions were $96^{\circ} \mathrm{C}$ for $10 \mathrm{~s}, 51^{\circ} \mathrm{C}$ for $5 \mathrm{~s}$ and $60^{\circ} \mathrm{C}$ for $30 \mathrm{~s}$ ( 25 cycles). A total of $0.5 \mu \mathrm{l}$ of shrimp alkaline phosphatase ${ }^{\circledR}$ (TAKARA, Dalian, China) was incubated with the ultimate product at $37^{\circ} \mathrm{C}$ for $1 \mathrm{~h}$ and at $75^{\circ} \mathrm{C}$ for 15 min which will inactivate the enzyme. A total of $8.5 \mu \mathrm{l}$ of Hi-Di Formamide $^{\circledR}$ and $0.5 \mu$ lof GeneScan-120 LIZ size standard ${ }^{\circledR}$ (Applied Biosystems) were mixed with $1 \mu \mathrm{l}$ of the purified minisequencing products. And then, the compound was denatured at $95^{\circ} \mathrm{C}$ for $5 \mathrm{~min}$. The raw data were collected using 3730 Genetic Analyzer Data Col- lection Software version $3.0^{\circledR}$ and then analyzed with GeneMapper Software v4.1 $1^{\circledR}$ (Applied Biosystems).

\section{Analysis of SOX2OT expression in BC tissues}

Total RNA were extracted from 41 patients' cancerous and noncancerous tissues using TRIzol reagent ${ }^{\circledR}$ (Invitrogen, CA, USA) following manufacturer's protocol. The quality and quantity of RNA were measured by Nanodrop ONE ${ }^{\mathrm{c}}$ spectrophotometer ${ }^{\circledR}$ (Thermo Fisher Scientific.) and stored at $-80^{\circ}$. The cDNA was synthesized with Moloney murine leukemia virus (M-MLV) reverse transcriptase ${ }^{\circledR}$ (Invitrogen, Carlsbad, USA).

The expressions of SOX2OT in tissues were detected by ABI 7900 HT fast Real-Time PCR system ${ }^{\circledR}$ (Applied Biosystems) with SYBR Green Assay (TAKARA, Dalian, China); the levels of $\beta$-actin were adopted as internal reference for normalization. All reactions were performed in triplicate.

\section{Statistical analysis}

Statistical analysis was performed by SPSS 23.0 software (IL, USA). Categorical variables are represented as percentages and continuous variables are described as the mean \pm standard deviation. A $\chi^{2}$ test was conducted for the Hardy-Weinberg equilibrium rule of the SNP loci of the rs 9839776 in SOX2OT gene. Odds ratios (ORs) and 95\% CI for genotypes were achieved under conditional logistic regression models. We considered p-values $<0.05$ as statistically significant.

\section{Results}

Participants' characteristics

Demographic and clinical characteristics of study subjects (505 BC cases and 601 controls) are illustrated in Table 1. There is no significant difference in age between

\begin{tabular}{|c|c|c|c|c|c|c|c|}
\hline \multirow[t]{2}{*}{ Genetic models } & \multirow[t]{2}{*}{ Genotypes } & \multicolumn{2}{|c|}{ Cases } & \multicolumn{2}{|c|}{ Controls } & \multirow[t]{2}{*}{ p-value ${ }^{\dagger}$} & \multirow{2}{*}{$\begin{array}{l}\text { Adjusted } \\
\text { OR }(95 \% \mathrm{Cl})^{\dagger}\end{array}$} \\
\hline & & $n=505$ & $\%$ & $n=601$ & $\%$ & & \\
\hline \multirow[t]{3}{*}{ Codominant } & $\mathrm{CC}$ & 220 & 43.6 & 315 & 52.4 & - & 1.00 (Ref.) \\
\hline & $\mathrm{CT}$ & 243 & 48.1 & 247 & 41.1 & 0.028 & $1.40(1.04-1.90)$ \\
\hline & TT & 42 & 8.3 & 39 & 6.5 & 0.144 & $1.54(0.86-2.73)$ \\
\hline \multirow[t]{2}{*}{ Dominant } & $\mathrm{CC}$ & 220 & 43.6 & 315 & 52.4 & - & 1.00 (Ref.) \\
\hline & $\mathrm{CT} / \mathrm{TT}$ & 285 & 56.4 & 286 & 47.6 & 0.018 & $1.42(1.06-1.90)$ \\
\hline \multirow[t]{2}{*}{ Recessive } & $\mathrm{CC} / \mathrm{CT}$ & 463 & 91.7 & 562 & 93.5 & - & 1.00 (Ref.) \\
\hline & TT & 42 & 8.3 & 39 & 6.5 & 0.348 & $1.30(0.75-2.27)$ \\
\hline \multirow[t]{2}{*}{ Alleles } & C & 683 & 67.6 & 877 & 73.0 & - & 1.00 (Ref.) \\
\hline & $\mathrm{T}$ & 327 & 32.4 & 325 & 27.0 & 0.022 & $1.31(1.04-1.66)$ \\
\hline
\end{tabular}


Table 3. Association between rs9839776 and clinical characteristics of breast cancer in a dominant model.

\begin{tabular}{|c|c|c|c|c|c|c|}
\hline \multirow[t]{2}{*}{ Variables } & \multicolumn{2}{|c|}{ CC (case/control) } & \multicolumn{2}{|c|}{ CT/TT (case/control) } & \multirow[t]{2}{*}{ p-value ${ }^{\dagger}$} & \multirow{2}{*}{$\begin{array}{l}\text { Adjusted } \\
\text { OR }(95 \% \mathrm{Cl})^{\dagger}\end{array}$} \\
\hline & $\mathbf{n}$ & $\%$ & $\mathbf{n}$ & $\%$ & & \\
\hline \multicolumn{7}{|l|}{ Age (years): } \\
\hline$->55$ & $127 / 175$ & $44.4 / 50.7$ & $159 / 170$ & $55.6 / 49.3$ & 0.193 & $1.29(0.88-1.90)$ \\
\hline \multicolumn{7}{|l|}{ Histological types: } \\
\hline - Invasive lobular carcinoma & $81 / 315$ & $41.3 / 52.4$ & $115 / 286$ & $58.7 / 47.6$ & 0.026 & $1.58(1.06-2.35)$ \\
\hline \multicolumn{7}{|l|}{ Differentiation grade: } \\
\hline - Well (G1) & $31 / 315$ & $56.4 / 52.4$ & $24 / 286$ & $43.6 / 47.6$ & 0.598 & $0.83(0.42-1.64)$ \\
\hline - Moderate (G2) & $155 / 315$ & $44.0 / 52.4$ & $197 / 286$ & $56.0 / 47.6$ & 0.037 & $1.41(1.02-1.95)$ \\
\hline - Poor (G3) & $34 / 315$ & $34.7 / 52.4$ & $64 / 286$ & $65.3 / 47.6$ & 0.013 & $2.00(1.16-3.45)$ \\
\hline- pT2 $(2-5 \mathrm{~cm})$ & $81 / 315$ & $39.1 / 52.4$ & $126 / 286$ & $60.9 / 47.6$ & 0.008 & $1.71(1.15-2.53)$ \\
\hline - pT3 $(\geq 5 \mathrm{~cm})$ & $15 / 315$ & $42.8 / 52.4$ & $20 / 286$ & $57.1 / 47.6$ & 0.399 & $1.44(0.62-3.36)$ \\
\hline - pT4 (exophytic) & $16 / 315$ & $64.0 / 52.4$ & $9 / 286$ & $36.0 / 47.6$ & 0.337 & $0.61(0.22-1.68)$ \\
\hline \multicolumn{7}{|l|}{ Nodal status: } \\
\hline$-\mathrm{pNO}$ & $149 / 315$ & $47.8 / 52.4$ & $163 / 286$ & $52.2 / 47.6$ & 0.264 & $1.21(0.87-1.69)$ \\
\hline$-p N 1$ & $58 / 315$ & $40.3 / 52.4$ & $86 / 286$ & $59.7 / 47.6$ & 0.033 & $1.64(1.04-2.58)$ \\
\hline$-p N 2$ & $13 / 315$ & $26.5 / 52.4$ & $36 / 286$ & $73.5 / 47.6$ & 0.008 & $2.93(1.33-6.47)$ \\
\hline \multicolumn{7}{|l|}{ Estrogen receptor: } \\
\hline - Positive & $132 / 135$ & $43.1 / 52.4$ & $174 / 286$ & $56.9 / 47.6$ & 0.032 & $1.45(1.03-2.04)$ \\
\hline
\end{tabular}

the two groups. In case group, $61.1 \%$ of $\mathrm{BC}$ patients are in invasive ductal carcinoma and $38.9 \%$ are in invasive lobular carcinoma. For differentiation, $11.0 \%$ of BC cases are in well grade (G1), 69.7\% in moderate grade (G2) and $19.3 \%$ in poor grade (G3). Besides, 238 (47.1\%), 207 (41.0\%), 35 (6.9\%) and 25 (5.0\%) patients are with a pT1, pT2, pT3 and pT4 tumor stage, respectively. For nodal status, 312 patients are in pN0 (61.8\%), 144 patients in N1 $(28.5 \%)$ and 49 patients $(9.7 \%)$ in $\mathrm{N} 2$. With respects to hormone receptors, $60.6 \%$ patients show positive ER and $54.7 \%$ patients show positive PR.

\section{SOX2OT expression in BC}

To confirm the role of SOX2OT in BC, we tested the SOX2OT RNA in 41 patients' both carcinoma and adjacent noncarcinoma tissues. In Figure 1A, the lncRNA SOX2OT displayed a significantly higher level in carci- noma tissues than in adjacent normal tissues $(\mathrm{p}<0.001$, Figure 1A). Considering the effect of hormones in BC, we evaluated the associations between SOX2OT expression and both estrogen receptor (ER) and progesterone receptor $(\mathrm{PR})$. As shown in Figure $1 \mathrm{~B}$ and $1 \mathrm{C}$, upregulations of SOX2OT existed in ER positive $\left(\mathrm{ER}^{+}\right)$group, $\mathrm{PR}$ positive group and PR negative groups $(\mathrm{p}<0.05)$, but not in ER negative (ER) group ( $p=0.065)$; the average expression of SOX2OT in BC tissues showed an unexpressed trend in the majority of ER patients' tissues (data were shown in Supplementary Data).

\section{Association between SNP rs9839776 \& BC risk}

In this case-control study, SNP rs9839776 in the SOX2OT gene were selected and quantified. The allele and genotype distribution for rs9839776 among participants were shown in Table 2. The genotype dis- 


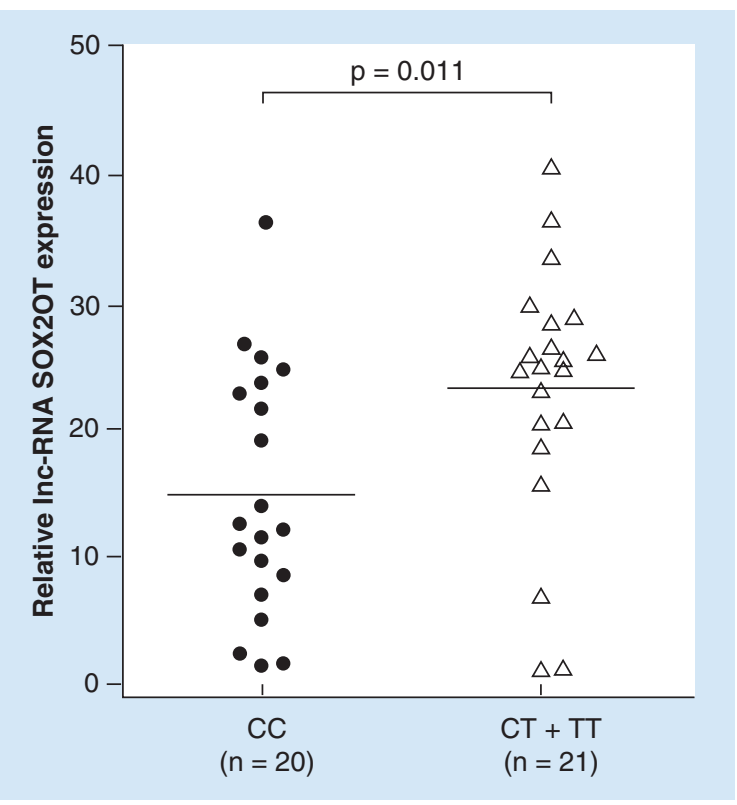

Figure 2. Relevance of IncRNA SOX2OT SNP rs9830776 and expression of IncRNA SOX2OT expression levels in breast cancer tissues. CC genotype $(n=20)$ versus CT+TT genotypes $(n=21), p=0.011$ in a codominant model.

tribution of rs9839776 in controls conform to the Hardy-Weinberg equilibrium $(p=0.396)$. Patients with T allele of rs9839776 in the SOX2OT gene had higher risk of $\mathrm{BC}$ compared with individuals carrying C allele in Chinese women, with OR of 1.31 (95\% CI: 1.04-1.66). After adjusted for age, the CT and TT genotypes showed significantly higher risk for $\mathrm{BC}$ compared with the CC genotype in the dominant model (adjusted OR: 1.42 ; 95\% CI: 1.06-1.90; p = 0.018). In the codominant model, the CT genotype significantly increased $\mathrm{BC}$ risk compared with the CC genotype (adjusted OR: 1.40; 95\% CI: 1.04-1.90; $\mathrm{p}=0.028$ ). However, in the recessive model, rs9839776 had no significant association with $\mathrm{BC}(\mathrm{p}=0.348)$.

\section{Stratified analysis of SNP genotypes \& BC risk characteristics}

We further examined the impacts of rs9839776 genotypes in $\mathrm{BC}$ on various disease characteristics in the patient cohort, including age, histological types, differentiation grade, tumor stage, nodal status, ER and PR in a dominant model. The results are shown in Table 3. For the patients younger than 55 , in the dominant model, combined genotypes (CT/TT) of rs9839776 had a significant 1.62-fold increase of $\mathrm{BC}$ risk compared with the genotype CC individuals (adjusted OR: 1.62; 95\% CI: 1.04-2.52; $\mathrm{p}=0.035)$. Besides, carriers with CT/TT genotypes and invasive lobular carcinoma histological type had a significantly higher BC risk (adjusted OR: 1.58; 95\% CI: $1.06-2.35 ; \mathrm{p}=0.026$ ). Furthermore, individuals with CT/TT were more prone to $\mathrm{BC}$ com- pared with CC (adjusted OR: 1.41; 95\% CI: 1.02-1.95; $\mathrm{p}=0.037$ for $\mathrm{G} 2$ and adjusted OR: 2.00; 95\% CI: 1.16$3.45 ; \mathrm{p}=0.013$ for $\mathrm{G} 3$, respectively). Based on these discoveries, we conclude that $\mathrm{CC}$ genotype has lower $\mathrm{BC}$ risk than CT/TT genotypes.

\section{The relationship of rs9839776 with IncRNA SOX2OT expression}

We revealed the impact of IncRNA-related SNP on SOX2OT expression. The influences of rs 9839776 different genotypes on SOX2OT expression is presented in Figure 2. Individuals with CT+TT genotype have significantly higher SOX2OT expression levels in BC tissues $(\mathrm{p}=0.011)$ than CC genotype.

\section{Discussion}

In this study, we have identified the impact of SOX2OT in BC. There is a higher expression level of SOX2OT mRNA in BC tissues, especially in $\mathrm{ER}^{+}$patients. The SNP rs 9839776 polymorphism in SOX2OT gene is genotyped, and evaluated for its association with BC risk in a Chinese women population. We have revealed that SNP rs9839776 in the SOX2OT gene is significantly associated with increased BC risk in Chinese women population. Patients carrying $\mathrm{T}$ allele of rs 9839776 have higher risk of BC compared with $\mathrm{C}$ allele. For women at age $\leq 50$ years, significantly higher risk of $\mathrm{BC}$ was found in individuals with CT/ TT genotypes of rs 9839776 than CC genotype (OR: 1.62; 95\% CI: 1.04-2.52), which is consistent with the conception that $\mathrm{BC}$ is a complex disease and its etiology is related to both genetic and reproductive factors.

SOX2OT gene locates in the 3q26.3-q27 locus of human chromosome and harbors SOX2 gene, which is one of the major regulators of pluripotency [17]. Unfortunately, the mechanism of SOX2 regulation has not been fully understood. So far, SOX2 has been discovered to participate in the generation process from adult human somatic cells to induced pluripotent stem cells, along with OCT4, c-Myc and Klf4 [18]. Recent research on squamous cell carcinoma of the skin tumors suggests that $S O X 2$ could take part in the promotion of tumor initiation and control of cancer stem cell properties [19]. While the exact role of SOX2OT is not yet clear, emerging evidence has demonstrated its positive role in transcription regulation of $\mathrm{SOX} 2$ gene. Several studies have demonstrated that the alterations of SOX2OT expression and corresponding expression change of SOX2 have been associated with BC [15]. A previous study analyzed the expression of lncRNA SOX2OT in BC tumor tissues and their corresponding adjacent noncancerous tissues and found that IncRNA SOX2OT showed significant overexpression in BC tumor tissues 
compared with adjacent noncancerous tissues [20]. Another experiment demonstrated that the expression of SOX2 is concordant with SOX2OT expression in $\mathrm{BC}$ samples, and $\mathrm{ER}^{+}$and $\mathrm{ER}^{-} \mathrm{BC}$ samples had distinct SOX2 and SOX2OT expression. They also demonstrated that increased SOX2 expression level was due to the ectopic expression of SOX2OT, which caused a decreased proliferation and increased BC cell anchorage-independent growth [21]. In our study, SOX2OT showed a lower expression in ER- BC tissues (Supplementary Data \& Figure 1), which partly supported the previous study. Besides, the rs9839776 polymorphism showed no significance in ER- BC tissues in our case-control study. This is a convincing evidence that in ER ${ }^{-} \mathrm{BC}$, the mechanism of SOX2OT and SOX 2 could be different from other types of BC.

According to the data of $B C$ gene expression from Cancer Genome Atlas and RNA sequencing data in BC tissues samples, the expression of SOX2OT is consistent with SOX2 in BC through elaborate analysis of the genome-wide RNA transcript profiles [15]. It has been widely accepted that the expression of adjacent antisense and overlapped genes could be regulated by $\operatorname{lncRNAs}$ through various mechanisms [22]. The intronic region of SOX2OT harbors SOX2 gene, a hypothesis that SOX2 expression could be regulated by SOX2OT gene was proposed. Several experimental results obtained from gene expression alteration during carcinogenesis have supported this hypothesis [23]. Thus, dysregulation of SOX2OT may play an important role in tumorigenesis and development of $\mathrm{BC}$ through the regulation of SOX2 expression. In our study, the rs9839776 CT+TT genotypes are significantly associated with a higher expression of SOX2OT, and T allele of rs9839776 in SOX2OT gene increased a 1.31-fold risk for BC in Chinese women. These results are mostly consistent with the previous studies and, therefore, we herein conclude that SNP rs9839776 results in ectopic expression of SOX2OT which causes higher SOX2 expression level, with an increased BC cell growth.

As limitations in our study, the inherent selecting bias and information bias were the major unavoidable problems, because all participants were recruited from hospitals. The second limitation could arise from the relatively small sample size, which impact the statistical power of our study. Third, the lack of HER2 information in patients enrolled in 2012 also limited further investigation for triple-negative BC. Last, the explicit mechanism of rs9839776 on regulating SOX2OT expression was still bewildered; increasing direct function experiments should be required.

\section{Conclusion}

In conclusion, we have confirmed the overexpression of lncRNA SOX2OT in BC tissues in Chinese female patients. Furthermore, we have identified significant association between SNP rs9839776 and BC risk. Also, the influcence of SNP rs9839776 on SOX2OT gene expression was pointed out. Our study provides a new insight on the relationship between SOX2OT gene and breast tumorigenesis, and contributes to the potential early detection of BC.

\section{Supplementary data}

To view the supplementary data that accompany this paper, please visit the journal website at: www.futuremedicine.com/ doi/full/10.2217/bmm-2016-0238

\section{Financial \& competing interests disclosure}

This study was mainly supported by the National Science Foundation (grant no. 81470089), and supported the National Science Foundation for Young Scientists of China (grant no. 81602919), Natural Science Foundation of Jiangsu Province (BK20151594), six talent peaks project in Jiangsu Province (WSW-017), Suzhou Key Technology Support program (SS201111), and Tianjin Municipal Major Scientific Technologic Special Project (15JCYBJC28300). The authors have no other relevant affiliations or financial involvement with any organization or entity with a financial interest in or financial conflict with the subject matter or materials discussed in the manuscript apart from those disclosed.

No writing assistance was utilized in the production of this manuscript.

\section{Ethical conduct of research}

The study is in compliance with the Declaration of Helsinki and approved by the Research Ethics Committee of Jiangsu Provincial Center for Disease Prevention and Control (No. 2012025).

\section{Open access}

This work is licensed under the Attribution-NonCommercialNoDerivatives 4.0 Unported License. To view a copy of this license, visit http://creativecommons.org/licenses/by-nc-nd/4.0/

\section{Executive Summary}

- Dysregulation of SOX2 overlapping transcript (SOX2OT) was significantly higher in breast cancer (BC) tissues than in normal tissues.

- C allele of SOX2OT rs9839776 polymorphism could cause the increased risk of BC.

- CC/CT genotypes of rs98396776 were strongly related to the higher expression of SOX2OT.

- SNPs rs98396776 could be a novel potential biomarker of BC. 


\section{References}

Papers of special note have been highlighted as:

- of interest; $\bullet \bullet$ of considerable interest

1 Jemal A, Bray F, Center MM, Ferlay J, Ward E, Forman D. Global cancer statistics. CA Cancer J. Clin. 61(2), 69-90 (2011).

2 Z C. (The third national death cancer survey in China). China Union Medical University Press, Beijing, China (2008) (In Chinese)

3 Coleman MP, Forman D, Bryant $\mathrm{H}$ et al. Cancer survival in Australia, Canada, Denmark, Norway, Sweden, and the UK, 1995-2007 (the International Cancer Benchmarking Partnership): an analysis of population-based cancer registry data. Lancet 377(9760), 127-138 (2011)

4 Hart CD, Migliaccio I, Malorni L, Guarducci C, Biganzoli L, Di Leo A. Challenges in the management of advanced, ER-positive, HER2-negative breast cancer. Nat. Rev. Clin. Oncol. 12(9), 541-552 (2015).

5 Sliwinska-Kowalska M, Pawelczyk M. Contribution of genetic factors to noise-induced hearing loss: a human studies review. Mutat. Res. 752(1), 61-65 (2013).

6 Bertone P, Stolc V, Royce TE et al. Global identification of human transcribed sequences with genome tiling arrays. Science 306(5705), 2242-2246 (2004).

7 Chiyomaru T, Yamamura S, Fukuhara S et al. Genistein inhibits prostate cancer cell growth by targeting miR-34a and oncogenic HOTAIR. PLoS ONE 8(8), e70372 (2013).

8 Zhang Z, Zhu Z, Watabe K et al. Negative regulation of IncRNA GAS5 by miR-21. Cell Death Differ. 20(11), 1558-1568 (2013).

9 Sheik Mohamed J, Gaughwin PM, Lim B, Robson P, Lipovich L. Conserved long noncoding RNAs transcriptionally regulated by Oct 4 and Nanog modulate pluripotency in mouse embryonic stem cells. RNA 16(2), 324-337 (2010).

10 Ma Y, Ma W, Huang L, Feng D, Cai B. Long non-coding RNAs, a new important regulator of cardiovascular physiology and pathology. Int. J. Cardiol. 188 105-110 (2015).

11 Roberts TC, Morris KV, Wood MJ. The role of long noncoding RNAs in neurodevelopment, brain function and neurological disease. Philos. Trans. R. Soc. Lond. B Biol. Sci. 369(1652), 20130507, (2014).

12 Liu J, Wan L, Lu K et al. The long noncoding RNA MEG3 contributes to cisplatin resistance of human lung adenocarcinoma. PLoS ONE 10(5), e0114586 (2015).
13 Chen G, Wang Z, Wang D et al. LncRNA Disease: a database for long-non-coding RNA-associated diseases. Nucleic Acids Res. 41, D983-D986 (2013).

14 Romero-Cordoba SL, Salido-Guadarrama I, RodriguezDorantes M, Hidalgo-Miranda A. miRNA biogenesis: biological impact in the development of cancer. Cancer Biol. Ther. 15(11), 1444-1455 (2014).

15 Shahryari A, Jazi MS, Samaei NM, Mowla SJ. Long non-coding RNA SOX2OT: expression signature, splicing patterns, and emerging roles in pluripotency and tumorigenesis. Front. Genet. 6, 196 (2015).

16 Boraska V, Franklin CS, Floyd JA et al. A genome-wide association study of anorexia nervosa. Mol. Psychiatry 19(10), 1085-1094 (2014).

- Displayed the significant SNPs in anorexia nervosa and these SNPs might be significantly associated with other diseases.

17 Fantes J, Ragge NK, Lynch SA et al. Mutations in SOX2 cause anophthalmia. Nat. Genet. 33(4), 461-463 (2003).

18 Takahashi K, Yamanaka S. Induction of pluripotent stem cells from mouse embryonic and adult fibroblast cultures by defined factors. Cell 126(4), 663-676 (2006).

19 Boumahdi S, Driessens G, Lapouge G et al. SOX2 controls tumour initiation and cancer stem-cell functions in squamouscell carcinoma. Nature 511(7508), 246-250 (2014).

20 Iranpour M, Soudyab M, Geranpayeh L et al. Expression analysis of four long noncoding RNAs in breast cancer. Tumour Biol. 37(3), 2933-2940 (2016).

- Displayed other potential three long noncoding RNAs which might also possess the functional SNP as the SOX2 overlapping transcript reported in our article.

21 Askarian-Amiri ME, Seyfoddin V, Smart CE et al. Emerging role of long non-coding RNA SOX2OT in SOX2 regulation in breast cancer. PLoS ONE 9(7), e102140 (2014).

-• Displayed a possible regulatory mechanism for SOX2 overlapping transcript in breast cancer.

22 Mercer TR, Dinger ME, Mattick JS. Long non-coding RNAs: insights into functions. Nat. Rev. Genet. 10(3), 155-159 (2009).

23 Amaral PP, Neyt C, Wilkins SJ et al. Complex architecture and regulated expression of the SOX2OT locus during vertebrate development. RNA 15(11), 2013-2027 (2009). 